\title{
Causes of Delay in Public Building Construction Projects: A Case of Addis Abeba Administration, Ethiopia
}

\author{
Abdurezak Mohammed Kuhil ${ }^{1}$ and Neway Seifu ${ }^{2}$ \\ ${ }^{1}$ Assistant Professor of Business Leadership, Addis Ababa University, \\ College of Business and Economics, School of Commerce, Ethiopia \\ ${ }^{2}$ Engineer, Zamra Construction PLC, Addis Abeba, Ethiopia \\ E-Mail: abdurazak.mohammed@aau.edu.et
}

\begin{abstract}
The time overrun in construction projects has become one of the most common problems in the industry that cause multitude of negative effects on the projects and its stakeholders. This study focused on assessing the main causes of delay in public building construction projects in Addis Ababa Administration mainly undertaken by grade one contractors. In these projects, 42 delay causing events in the Addis Ababa public building construction projects were identified and categorized in to five main category groups, and the most important and critical causes of public building construction delay causing factors were evaluated and ranked based on the RRI(Ranking and computation of relative importance index)values from the data collected in a questionnaire survey of three groups of respondents- clients, consultant and contractors in the construction industry. The survey findings revealed the top ten factors that cause construction delays in the public building construction projects in Addis Ababa are: (1) Difficulty in project financing (poor financial system); (2) Poor Project management system;(3) Delay in issuance of designs and working drawings; (4) Shortage of availability of imported construction materials and goods on market; (5) Design errors and complexity of designs;(6)Delay in progress payments for completed works; (7) Late start \& resource mobilization to site; (8) Financing problems; (9) Inaccurate Site investigation Report;(10) Price Inflation. Furthermore, the ranking of the factors tested the agreement among the respondents and finally agreement test reveal that there appears a positivecorrelation between the groups in noticing and ranking the set of delay causes. The study recommended in general and particularly to all the parties for mitigating factors causing time overrun.

Keywords: Construction projects delay, Time overrun, Public Building Construction, Delay Causes, Top-Ten Delay Factors
\end{abstract}

\section{INTRODUCTION}

A construction project is commonly acknowledged as successful, when it is completed on schedule, within budget and within the agreed quality, in compliance to the specifications and to stakeholders' satisfaction. Functionality, profitability to contractors, absence of claims and court proceeding and "fitness for purpose" for occupiers have also been used as measures of project success(Assaf\& Al-Hejji, 2006).The construction industry in Ethiopia, as in most developing countries, has made a significant contribution to the growth of the economy through infrastructure development and job creation. Public construction projects are parts of the country's development initiative; they share considerable amount of the country's scarce financial resources.

In Ethiopia in general and in Addis Abeba Administration in particular,, the construction industry is the highest recipient of government budget in terms of government development programs. Consequently, public construction projects consume an average annual rate of nearly $60 \%$ of the government's capital budget as reported by Ministry of Works and Urban Development (MoWUD, 2006).The rapid growth of population in Addis Ababa presents extraordinary pressure on the existing housing policy and on the entire infrastructure like- water, electrical power supply, drainage and road. For example, The Ethiopian Federal Democratic Government took considerable effort to improve the housing conditions in Addis Ababa city by maintaining different housing programs like- 10/90, 20/80 and 40/60 schemes respectively. Many public building construction projects in Ethiopia suffer delay, only $8.25 \%$ projects were finished on the original targeted completion date and the remaining $91.75 \%$ delayed $352 \%$ of its contractual time (Werkuand Jha, 2016).

The time overrun in construction projects has become one of the most common problems in the industry that cause multitude of negative effects on the projects and its stakeholders. The consequences of these delays include; cost overruns, loss of profits, increased overheads, stress, and dispute between parties, litigation and loss of opportunities. Therefore, this aspect has been constantly investigated by researchers across the world with a great enthusiasm in order to identify the root causes of the delay to come up with corrective measures.

Building construction projects are exposed to many problems during construction phase that lead to the unnecessary delay and to meet the deadline of the project. It is common to people blame one party (the contractor, the consultant or the client), commonly the contractor, without giving due consideration to the stakeholders involved in the particular project. Therefore, to ensure that public building construction projects can run smoothly without any delay, knowledge and understanding of the problems encountered during the construction process to each stakeholder should be conducted thoroughly. 


\section{OBJECTIVES OF THE STUDY}

The main purpose of the study is to identify the main causes of delay that affect the smooth completion of public building construction projects in Addis Ababa. Particularly to identify the main causes of delay during construction phase and identify and rank the delay causes attributed to each stakeholder mainly to client, contractor and consultant involved in the projects and state the top ten delay causes of the public construction projects according to clients, consultants, and contractors and combined views.

\section{LITERATURE REVIEW}

Time is one of the major considerations throughout project management life cycle and can be regarded as one of the most important parameters of a project and the driving force of project success in addition to cost and quality. Hence completing projects on time is an indicator of efficiency and project success, but it is almost common that the construction process is subjected to many variables and unpredictable factors.

Delay is generally acknowledged as the most common, costly, complex and risky problem encountered in construction projects, (Asaf \& Al-Hejji, 2006)revealed that delay in construction is a global phenomenon affecting not only the construction industry but also the overall economy of countries as well. The researchers (Assaf and Al-Hejji, 2006)have identified that the main causes of delay are due to three participating parties namely clients, contractors, and consultants. According to clients are: contractors' improper planning, contractors' poor site management, subcontractors issue and skilled labor supple and productivity. According to contractors are: insufficient clients' payments to completed and ongoing works, subcontractors' issue, acquiring difficulties for work permit and approval, and availability and failure of equipment. According to consultants and engineers are: slow decisions of clients, contractors' poor site management, contractors' improper planning, insufficient clients' payments to completed and ongoing works, and shortage of equipment and material.

Time overruns is defined as the difference between the actual completion time and the estimated completion time (Aibinu \& Odeyinka, 2006). Time overrun as the time during which some part of construction project is completed beyond the project completion date or nor performed as planned due to an unanticipated circumstance. This is called project delay because the project completion date is to be extended. Construction delays can be defined as the late completion of work compared to the planned schedule or contract schedule. Construction delays can be minimized only when their causes are identified. According to (Seboru, 2015)the word "delay" is defined as something happening at a later time than planned, expected, specified in a contract or beyond the date that the parties agreed upon for the delivery of a project. Delay is slowing down of work without stopping construction entirely and that can lead to time overrun either beyond the contract date or beyond the date that the parties have agreed upon for the delivery of the project. Failure to achieve targeted time, budgeted cost and specified quality result in various unexpected negative effects on the projects. Usually, when the projects are delayed, they are either extended or accelerated the time and therefore, invite to the additional cost.

Ogunlana, prokutong and Jearkjirm and (1996); Lo TY, Fung IWH \& Tung KCF.(2006); Chan DWM, Kumaraswamy MM.(1997); Aibinu A, Odeyinka H. (2006) have identified many remarkable causes of delays such as: weather conditions, shortages of resources, shortage of materials and equipment, financial difficulties faced by clients and contractors, poor contract management etc. Different authors and researchers have different perceptions about causes of delays. The loss of control on time leads to failure of projects and the shortage of control may be caused as a result of lack of knowledge and awareness. Completing projects within the time is an indicator of an efficient construction industry. The ability to estimate the completion time is normally dependent on the individual intuition, skill and experience of the planning engineer. Reaching to the end of any project is not a kind of success for the project owner. According to(Menasi, 2007), delays may be caused by the owner (compensable delay), by the contractor (nonexcusable delay), by acts of god, or a third party (excusable delay), or several different kinds of delays may happen either together or separately and affect the critical path of the project (concurrent delays).similarly, delays also classified as critical and non-critical. From literature review the conceptual model for delay causes in construction projects was depicted and used for this study.

\section{RESEARCH METHODOLOGY}

The research was mainly based on respondents' view using a structured type of questionnaire which was prepared using a five point Likert scale (extremely important, very important, moderately important, slightly important and not important). In the public building construction projects that are the target of this project work, from the lists of causes of delay discussed in the literature review, the most probable causes were sorted out and organized in a way to help understand the respondents. As a result, questionnaires with the list of 42 causes of delay were grouped in 5 main categories.

In determining the sample size, the study has considered the most common technique applied in such situationsYamane's model (1967). In this model, the number of sampled representatives is computed by considering the total population size, required minimum confidence level, and tolerable sampling error as presented below.

$\mathrm{n}=\mathrm{N} /\left(1+\mathrm{N}(\mathrm{e})^{2}\right)$

Where $\mathrm{n}=$ sample size

$\mathrm{N}=$ population size

$\mathrm{e}=$ sampling error/level of precision 
As per the data collected form Addis Ababa Construction Bureau given total grade one construction contractors undertaking public funded building construction projects in the city administration were 28 and the maximum standard error set to be $5 \%$ the sample size of the respondents is computed as follows.

$\mathrm{n}=28 /\left(1+28(0.05)^{2}\right)=26$

Therefore, the minimum number of respondents will be 26 . Based on the sample size, 82 questionnaires were distributed, of which 28 questionnaires to contractors, 28 to consultants and 26 to clients/ owners were distributed. From the distributed questionnaire 28, 25 and 15 questionnaires were returned by contractors, consultants and clients respectively.

The data was collected from the experienced respondents of on the targeted projects. The analysis of causes of delay in the construction project was using relative important index (RII) and correlation coefficient using Microsoft excels..

Relative Importance Index (RII): used to determine the relative importance of the various causes of delay using five-point Likert scale. The higher value of the relative important index (RII) represents the important cause of delay and Computed by Equation

$$
\begin{aligned}
& R I I=\frac{\sum W i F i}{A * N} \\
& =\frac{1 * F 1+2 * F 2+3 * F 3+4 * F 4+5 * F 5}{5 * N}
\end{aligned}
$$

Where

i - Response category index,

Wi - The weight given by respondents,

$\mathrm{Fi}$ - The frequency of respondent for each weight,

A - The highest weight (5 in this case) and

$\mathrm{N}$ - The total number of respondents.

RII -The relative important index ranges from 0 to 1.

Data collected from the different groups were analyzed and critically interpreted to answer the main objective of the study. The spearman's rank correlation coefficient, rs was used to measure and compare between the rankings of clients consultants, contractors and combined view for a single cause of delay. Therefore spearman rank correlation is use to consolidate the responses from the three stake holders to a single cause of delay.

The value of Rs ranged from -1 to 1 and indicated as;

1. if -1 or +1 perfect negative or positive agreement /correlation,

2. between -1 to -0.5 or 1 to 0.5 ,strong negative or positive correlation /agreement,

3. between -0.5 to 0 or 0 to 0.5 , weak negative or positive correlation and

4. 0 no correlation /agreement (Fallahnejad, 2013)

Spearman's rank Computed using Equation
Where

$$
r s=1-\frac{\left(6 \sum d^{2}\right)}{\left(n^{3}-n\right)}
$$

$\mathrm{r}_{\mathrm{s}}=$ Spearman's rank,

$\mathrm{d}=$ rank difference,

$\mathrm{n}=$ number of ranks.

\section{MAIN FINDINGS OF THE STUDY}

The results of the data collected by using the devised questionnaire survey, which was distributed among professionals working in the construction industry of Addis Ababa City, is presented and discussed in this section. The main objectives of this survey, which analyses data and answer the research questions. It presents and ranks the causes of delay based on the opinions of the three different groups using relative importance index separately and in group. It also tests the agreement of respondents (clients, contractors and consultants) with correlation of the ranks using spearman's coefficient.

The questionnaire distributed to clients/owners, consultants and contractors participating in the selected public building construction projects, was responded by project managers, resident engineers, construction contract administrators, site engineers, office engineers and other senior officials having different capacities related to the public building projects. The data collected was analyzed and ranked the causes of delay through RIIusing Microsoft Excel.

The objective of conducting the analysis for this section is to establish the factors under the groups of causes identified from the literature review and ranking them according to their significant influence towards the delay in construction projects.

These causes are classified in to five main categories. (1) Client/owner related cause, (2) contractor related causes, (3) consultant related causes (4) resource related causes material, equipment and man power and (5) external causes.

Ranking of the delay causing factors based on RII was calculated to reveal the most influential factors within each category of causes and from all causes in general. The group of respondents (the clients, consultants and contractors) has prioritized the causes of delay from the set of causes in order of their importance. A combination of the perception of each group was also stated. Therefore, form the combined (clients', consultants' and contractors') view it can be perceived that the first and second causes are from the contractor related category and the third, two events, from consultant and resource related category.

The top 10 most events that cause delay to construction projects is indicated and listed according to the three responding groups. In addition, in the study the top ten causes of the combined perceptions of all the groups is stated. Therefore, according to the combined view, as shown in the table below, all the parties have recognized 
that 'difficulty in project financing', 'poor project management system' and 'late issuance of designs, 'shortage of availability of imported construction materials' are among the ten most significant factors causing time overrun.

TABLE I COMBINED VIEW TOP TEN DELAY CAUSES

\begin{tabular}{|c|c|c|c|c|}
\hline ID & Causes of delay & RII & Rank & Category \\
\hline 12 & $\begin{array}{l}\text { Difficulty in project financing ( poor financial } \\
\text { system) }\end{array}$ & 0.847 & 1 & Contractor related \\
\hline 10 & Poor Project management system & 0.818 & 2 & Contractor related \\
\hline 20 & $\begin{array}{l}\text { Delay in issuance of designs and working } \\
\text { drawings }\end{array}$ & 0.812 & 3 & Consultant related \\
\hline 35 & $\begin{array}{l}\text { Shortage of availability of imported construction } \\
\text { materials and goods on market }\end{array}$ & 0.812 & 3 & Resource related \\
\hline 23 & Design errors and complexity of designs & 0.791 & 5 & Consultant related \\
\hline 4 & $\begin{array}{l}\text { Delay in progress payments for completed } \\
\text { works }\end{array}$ & 0.779 & 6 & Client related \\
\hline 11 & Late start \& resource mobilization to site & 0.779 & 6 & Contractor related \\
\hline 3 & Financing problems & 0.776 & 8 & Ceint related \\
\hline 19 & Inaccurate Site investigation Report & 0.771 & 9 & Consultant related \\
\hline 37 & Price Inflation $\quad-\quad b$ & 0.768 & 10 & External related \\
\hline
\end{tabular}

In the table above it is reflected that each responding parties (client, consultant and contractor) has got different perceptions towards the delay causes category. The following table II shows the perception of clients, consultant and contractors towards the category of the delay causes.

TABLE II PERCEPTIONS OF CLIENTS, CONSULTANT AND CONTRACTORS TO CATEGORY OF DELAY CAUSES

Causes of Delay in Public Building Construction Projects, Category wise

\begin{tabular}{|c|c|c|c|c|c|c|c|c|c|}
\hline \multirow[t]{2}{*}{ No. } & \multirow[t]{2}{*}{ Causes of Delay Category } & \multicolumn{2}{|c|}{$\begin{array}{l}\text { Client/Owner } \\
\text { Perceptions }\end{array}$} & \multicolumn{2}{|c|}{$\begin{array}{l}\text { Consultant } \\
\text { Perceptions }\end{array}$} & \multicolumn{2}{|c|}{$\begin{array}{l}\text { Contractor } \\
\text { Perceptions }\end{array}$} & \multicolumn{2}{|c|}{ Combined Perception } \\
\hline & & RII\% & Rank & RII\% & Rank & RII\% $\%$ & Rank & RII\% & Rank \\
\hline $\mathrm{i}$ & Client/Owner Related Causes & 0.633 & 4 & 0.7 & 2 & 0.787 & 1 & 0.721 & 4 \\
\hline ii & Contractor Related Causes & 0.794 & 1 & 0.724 & 1 & 0.727 & 4 & 0.741 & 1 \\
\hline iii & Consultant Related Causes & 0.753 & 2 & 0.671 & 4 & 0.767 & 2 & 0.729 & 2 \\
\hline iv & $\begin{array}{l}\text { Resource related Causes } \\
\text { (Material, Equipment and Man } \\
\text { power) }\end{array}$ & 0.752 & 3 & 0.681 & 3 & 0.744 & 3 & 0.722 & 3 \\
\hline $\mathbf{v}$ & External Causes & 0.591 & 5 & 0.605 & 5 & 0.641 & 5 & 0.617 & 5 \\
\hline
\end{tabular}

According to the combined perception of all responding parties, it is perceived that contractor related (RII 0.741), consultant related (RII 0.729), resource related (RII 0.721), client/owner related (RII 0.722) and external related (RII 0.617) are placed from first to fifth. Spearman rank correlation is use to consolidate the responses from the three stake holders to a single cause of delay. Hence, to test the agreement and disagreement among the responding parties (client, consultant and contractor) and the combined view, the rank correlation coefficients between two parties for all combinations for the selected category groups of factors are depicted in the following table.

Table III and IV shows spearman rank correlation coefficient $\left(\mathbf{r}_{\mathrm{s}}\right)$ between client, contractor, consultant and combined result for inside category ranking and overall ranking of causes. In this analysis the correlation coefficient result between client - consultant, consultant - contractor, client- combined, consultant - combined and contractor combined and views are perfectly in line with each other when it comes to the external related category causes.

In the rest four category all the correlation coefficient of the parties to one another ranges from 0.952 to 0.988 this in turn lies between +0.5 to +1.0 , consequently this clearly indicates that there is strong correlation or agreement on the four category rankings except the external category cause which shows perfect correlation. In addition the correlation coefficient for overall ranking of the delay causes in all categories is presented in the below table IV as following. 
TABLE III CORRELATION COEFFICIENT ( $\mathbf{R}_{\mathbf{S}}$ ) AMONG RESPONDENTS' IN CATEGORY WISE RANKING

\begin{tabular}{|c|l|c|c|c|c|c|c|}
\cline { 3 - 8 } No. & Category & $\begin{array}{c}\text { Client Vs } \\
\text { Consultant }\end{array}$ & $\begin{array}{c}\text { Client vs } \\
\text { Contractor }\end{array}$ & $\begin{array}{c}\text { Consultant rs } \\
\text { Conractor }\end{array}$ & $\begin{array}{c}\text { Client vs } \\
\text { Combined }\end{array}$ & $\begin{array}{c}\text { Consultant rs } \\
\text { Combined }\end{array}$ & $\begin{array}{c}\text { Contractor rs } \\
\text { Combined }\end{array}$ \\
\hline 1 & Client /Owner Related & 0.952 & 0.952 & 0.988 & 0.976 & 0.988 & 0.994 \\
\hline 2 & Contractor Related & 0.97 & 0.952 & 0.97 & 0.982 & 0.994 & 0.988 \\
\hline 3 & Consultant Related & 0.982 & 0.994 & 0.988 & 0.994 & 0.994 & 1 \\
\hline 4 & Resource Related & 0.988 & 0.988 & 0.994 & 0.994 & 0.994 & 1 \\
\hline 5 & External Related & 1 & 0.994 & 1 & 1 & 1 & 1 \\
\hline
\end{tabular}

TABLE IV COEFFICIENT OF CORRELATION FOR OVERALL RANKING OF DELAY CAUSES

\begin{tabular}{|c|c|c|c|c|c|c|}
\cline { 2 - 7 } & \multicolumn{5}{|c|}{ Correlation Coefficient $\left(\mathbf{r}_{\mathbf{s}}\right)$ Overall Ranking } \\
\hline Causes of Delay & $\begin{array}{c}\text { Client Vs } \\
\text { Consultant }\end{array}$ & $\begin{array}{c}\text { Client vs } \\
\text { Contractor }\end{array}$ & $\begin{array}{c}\text { Consultant } \\
\text { vs } \\
\text { Conractor }\end{array}$ & $\begin{array}{c}\text { Client vs } \\
\text { Combined }\end{array}$ & $\begin{array}{c}\text { Consultant } \\
\text { vs } \\
\text { Combined }\end{array}$ & $\begin{array}{c}\text { Contractor } \\
\text { vs } \\
\text { Combined }\end{array}$ \\
\hline $\begin{array}{l}\mathbf{r}_{s} \text { Overall Ranking } \\
\text { for Causes of Delay }\end{array}$ & 0.893 & 0.88 & 0.939 & 0.938 & 0.968 & 0.977 \\
\hline
\end{tabular}

Finally when the overall ranking coefficient of correlation is investigated, the value lies in the range between +0.5 to +1.0 this shows all the respondents are strongly correlated to the overall ranking.

\section{CONCLUSION}

This project work has focused on causes of delay of public building construction projects in Addis Ababa city. The study has assessed and identified the main delay causes. Accordingly, the main delay causes are client, consultant, contractor, resource and external related causes. The study sought the views of clients, consultants, and contractors on the relative importance of the factors that cause delays in public building construction projects in Addis Ababa. In the study the top ten delay causes according to the view of the three participating parties (clients, consultants, contractors) and combination of all is stated and listed in a rank according to the IRR values.

The study also showed that all the three groups of respondents generally agreed on the 42delay factors stated. The most significant and top ten factors causing time overrun identified in this project work based on the perceptions of all the three main parties combined. Generally in the study the causes of delay are ranked according to their importance from rank 1 to 42 . And in addition the top ten delay causes were explicitly indicated according to the view of the three responding parties (clients, consultants, contractors) and combination of all is stated and listed in a rank accordingly.
According to the owners respondents the following delay factors are ranked from one to four: Poor Project management system, late start \& resource mobilization to site, difficulty in project financing (poor financial system) and Shortage of availability of imported construction materials and goods on market. For consultants the most important delay factors which took the highest rank are the following: difficulty in project financing (poor financial system), delay to furnish and deliver the site to the contractor, delay in issuance of designs and working drawings and slow in decision making. According to the contractors' perceptions the main important and the top four delay causes are: delay in progress payments for completed works, difficulty in project financing (poor financial system), financing problems and delay in issuance of designs and working drawings. Finally the study also showed that all the three groups of respondents positively agree on the rankings of 42delay factors stated. Clientconsultant and consultant- contractor have positive strong agreement, and clients and contractors have weak positive agreement on the rankings.

\section{RECOMMENDATION}

As can be observed from the results of the combined or overall perceptions, the top ten most important delay factors arise from all the participation parties (clients, consultants and contractors). The recommendations made in general and particularly to all the parties for mitigating factors causing time overrun based an expert opinion are the following: 


\section{A. For Owners}

1. Owners should possess a comprehensive financial plan and cash flow enough to finance the construction projects on hand to avoid the project financing problems.

2. Owners should effect immediately payment of the dues to the contractor for the work being carried as well as the payments of finished items according to the terms of the contract.

3. Need to make sufficient time available for consultants to do a proper design.

4. Owners should make sure tender documents are complete, clear and free of errors and/or contradictions.

5. Owners should hire competitive and experienced contractors and consultants in the field of works.

\section{B. For Consultants}

1. Consultants should avoid delaying the response to contractors' queries as well as the approval of submitted materials and shop drawings.

2. Consultants should prepare a comprehensive and final designs and working drawings ahead to the commencement of works by the contractor and hold a sufficient number of design review sessions with the client before finalizing the design.

3. Should avoid design errors and complexity of designs

4. Should establish strong contract administration cervices to control and evaluate variation orders initiated by owners.

5. Should have a thorough knowledge on the site conditions where the construction project is to be erected.

\section{For Contractors}

1. Should develop a comprehensive financial plans and cash flows, to avoid the poor financing system of the project on hand.

2. Should establish strong project management system led by professionals who mobilize and who understand the critical activities to handle and mitigate any delay that may rise during construction activities.

3. Should mobilize resources and should start commencement of works immediately after possession of site.
4. Should prepare materials procurement plan and state the lead time ahead for imported construction materials to minimize the delay caused from shortage of the imported resources.

5. Every attempt must be made to retain the same labor gang throughout project duration.

\section{LIMITATIONS OF THE STUDY}

The researchers believe that this study was limited to one city Administration and probably requires further study to conclude at public construction projects level in the country.

\section{REFERENCES}

[1] Aibinu, A., \& Odeyinka, H. (2006). Construction Delays And Their Causative Factors In Nigeria. Journal of Construction Engineering and Management, 667-677.

[2] Asaf, S. A., \& Al-Hejji, S. (2006). Causes of delay in large construction projects. International journal of project management, 349-357.

[3] Chan DWM., \& Kumaraswamy, MM. (1996). A comparative study of causes of time overruns in construction project. Hong Kong. Int J project manage, 15 (1): 55-63.

[4] Fallahnejad, M. (2013). Delay Causes in Iran gas pipeline projects. International Journal of project management, 31 .

[5] Lo, T. Y., Fung, I. W. H., \& Tung, K.C. F. (2006). Construction delays in Hong Kong civil engineering projects, Journal of Construction Engineering and Management.

[6] Menasi, W. (2007). construction delay analysis under multiple baseline updates,A Thesis Presented to the University of Waterloo in partial fullfilment of masters of science in civil engineering,waterloo university. ontario,canada.

[7] Ministry of Works and Urban Development (MOWUD,2006). Plan for Accelerated and Sustained Development to end Poverity (PASDEP). Addis Ababa.

[8] Ogunlana, S. O., Promkuntong, K., \& Jearkjirm, V. (1996). Construction delays in a fast-growing economy: comparing Thailand with other economies. International Journal of Project Management, 14(1), 37-45.

[9] Seboru, M. A. (2015). An Investigation into Factors Causing Delays in Road Construction Projects in Kenya. American Journal of Civil Engineering , 3(3), 51-63.

[10] Werku Koshe\& Jha, K. N. (2016). Investigating Causes of Construction Delay in Ethiopian Construction Industries, Journal of Civil, Construction and Environmental Engineering, 1(1), 18-29.

[11] Yamane, Taro. (1967). Statistics, An Introductory Analysis, 2nd Ed., New York: Harper and Row. 